\title{
Tuition and Social Class in the Russian Universities: S. S. Uvarov and "Reaction" in the Russia of Nicholas I
}

S. S. Uvarov, minister of education from 1833 to 1849 , is usually described as a reactionary. The reason for that judgment is clear. Many of the steps Uvarov took as minister seemed designed to block the realization of the liberal goals set by the reformers who assisted Alexander $I$ in founding the modern Russian educational system in 1801-4. One important aspect of that liberal, modern, system was its "all-class" character. An educational system which admitted students of all classes was perceived by "reactionaries" as a threat to the established order, despite the relatively small numbers of people involved. Thus, "Uvarov was disturbed by the trickle of students from lower classes who were finding their way into the universities. As in secondary schools, the admission of such students was hindered by legalistic formalities and an increase in tuition fees." 1

The present paper argues that the usual picture of Uvarov's methods and goals, outlined above, is not only incorrect, but also obscures a point important for an understanding of the dilemma which the need for "modernization" presented imperial Russia. Uvarov did not introduce, nor increase, tuition fees in order to keep out students from the lower classes, nor did the fees charged have that effect. He did attempt to avoid fundamental change in the system, for he believed that the Russian class system and the Table of Ranks created by Peter the Great promised a society superior to those of neighboring countries, where inclusion in the upper classes, in

1. Michael T. Florinsky, Russia: A History and an Interpretation, 2 vols. (New York, 1960), 2:804. Florinsky's information and analysis are taken from P. Miliukov, Ocherki po istorii russkoi kul'tury, vol. 2. Miliukov's study went through several editions, 1896 (St. Petersburg) to 1931 (Paris), but only the pagination, not a word of the text on educational matters, was changed in the successive editions. Florinsky cites the Paris edition. Florinsky's account is typical of both Western and Russian accounts in following Miliukov and in assuming that tuition was a device Uvarov introduced to impede admission of lower class students. For examples, see P. L. Alston, Education and the State in Tsarist Russia (Stanford, 1969), pp. 35-36; W. H. E. Johnson, Russia's Educational Heritage (Pittsburgh, 1950), p. 100; M. Polievktov, Nikolai I: Biografia i obsor tsarstuozaniia (Moscow, 1918), p. 240; V. V. Mavrodin, ed., Istoriia Leningradskogo Universiteta (Leningrad, 1969), pp. 58-59.

The author gratefully acknowledges the support of the Russian Research Center, Harvard University. 
Uvarov's view, depended on birth or the acquisition of wealth rather than service to society. ${ }^{2}$

Few have found it easy to empathize with Uvarov's view of the promise contained in Russia's class system. ${ }^{3}$ The horror of serfdom alone earned the contempt of many abroad and the undying enmity of many within Russia. Nonetheless, the ideal behind the system was service. All groups owed "obligations" to society through the state. The nobility's obligation was to serve the tsar, primarily as his military officer corps, and to be the government at the local level. The situation was complicated, however, because, in 1762, Peter III had freed the nobility of the legal obligation to serve. While the option to serve, or not, was seldom a serious matter of choice-most nobles, both economically and psychologically, continued to need admission to the state service-the tsar's action transformed them into Russia's only "free" class. The situation was further complicated by Peter the Great's Table of Ranks. Peter's creation rewarded state service, both military and civil, with promotion into the ranks of the hereditary nobility. Thus nobility in Russia depended on birth or service or some combination of the two. Although Catherine the Great, in 1785 , attempted to simplify the class system by setting out definitions which grouped Russia's population into four "main types of people," her effort failed and the classes continued to number in the dozens or, by some calculations, in the hundreds. An additional complication was the possibility that an individual might in effect belong to two classes at the same time. After 1807 , for example, a gentryman might join a merchant guild without giving up his gentry status, and the "free labor" hired to work for wages in factories, usually recruited from private or, more rarely, state owned peasants, retained the legal "class" obligations of the peasant class, even though their occupations and way of life might have changed completely.

In general, however, all classes except gentry could be assumed to be "obligated," though that term remained undefined. Indeed, the significance of even the term "class" (soslovie) was not entirely clear, for it was seldom used in the Code of Laws, and even when used was given various meanings. "Obligated" normally meant those subject to the military draft and the head tax. Yet, since Russian classes were also usually occupation groups, their "obligations" included serving the state by performing the duties of their "class." Thus, a Russian "class" might be a hereditary "estate," a rank

2. Uvarov to Nicholas, February 1847, printed in V. A. Evreinov, Grazhdanskoe chinoproisvodstvo v Rossii (St. Petersburg, 1887), pp. 82-85.

3. For example, Hans-Joachim Torke, "Das russische Beamtentum in der ersten Halfte des 19 Jahrhunderts," Forschungen zur Osteuropäischen Geschichte, vol. 13 (Berlin, 1967), p. 85, judges Uvarov's report, cited above, as "pathetic." 
or set of ranks in the state services, a corporation or institution, an occupational group or an ethnic or religious group, or some combination of two or more of these elements. ${ }^{4}$

The reformers who founded the Russian university system in 1803-4 met the problems stemming from the complexities of the class system in the simplest way possible-by ignoring them. The founding legislation made no mention of class, but said only that admission to a university was open to all who could meet the academic requirements. Also, no provision was made for tuition. Students were either "state students" supported by the government or "self-supporting." State students were committed to a period of service, usually six years, upon graduation, but actually all students were expected to enter state service. Indeed, the founding legislation defined the university as the institution of higher learning in which "youth prepare for entrance to the various branches of state service."5 Thus, from the government's point of view, it made sense to recognize university degrees with places in the Table of Ranks for state servitors.

Initially, there were so few candidates willing and able to do university work that few problems arose over admitting students. The question became whether students from "obligated" classes left their classes through education. Alexander, in 1811, clarified the issue somewhat by ruling that although the universities had been founded so that "all might contribute through learning to the welfare of the nation," a student did not leave his class by "mere admission" to a university. Rather, the student had to complete the "whole course" in order to qualify for a new status in society. ${ }^{6}$ Two years

4. A brief outline can hardly do justice to the subject of Russian classes. Useful brief treatments are the article on "classes" (sosloviia) in Entsiklopedicheskii sloviar', vol. 30 (St. Petersburg, 1900), pp. 911-13 and the article on "obligated classes" (podatnyia sostoianiia) in ibid., vol. 24 (St. Petersburg, 1898), pp. 46-47. For insightful discussions of the gentry see R. E. Jones, The Emancipation of the Russian Nobility 1762-1785 (Princeton, 1973), especially pp. 273-99; Terence Emmons, The Russian Landed Gentry and the Peasant Emancipation of 1861 (Cambridge, 1968), especially pp. 3-29. W. L. Blackwell, in The Beginnings of Russian Industrialization 1800-1860 (Princeton, 1968), pp. 100 -110, provides an exceptionally lucid summary description of the urban classes, including gentry and peasants in their urban roles; while W. M. Pintner, Russian Economic Policy under Nicholas I (Ithaca, 1967), pp. 55-67, presents an informative discussion of the finance ministry's hopes for developing a "middle class" out of the various urban classes. On the rural classes, see Jerome Blum, Lord and Peasant in Russia (Princeton, 1964), especially pp. 475-503 dealing with the "peasant" classes other than the gentry's serfs. In this paper, the term "obligated" will refer to all groups except gentry and "officers," that is, those promoted to ennobling ranks in the services, since that was the usual practice of the Ministry of Education in the Uvarov years.

5. Sbornik postanovlenii po ministerstzn narodnago prosveshcheniia, 15 vols. (St. Petersburg, 1875-1902), 1:295 (Statute of universities, November 5, 1804).

6. Ibid., p. 759 (Ukaz, November 10, 1811) ; Sbornik rasporiashenii po ministerstvu narodnago prosveshcheniia, 6 vols. (St. Petersburg, 1866-1901), 1:223-24 (Po voprosu. ... September 18, 1813). 
later, in response to a request for guidance from Kharkov University regarding a serf, the minister of education ruled that it would be "better" to liberate the serf before admission. By 1815, these two decisions had formed the basis for a system. In order to enter a university (or gymnasium, the university preparatory school) a student from an obligated class had to present written evidence from his legal authority, certifying release from his class. However, the student completed his release from his class only upon successful completion of the university course, when the Senate would issue a document certifying his new rank in society. ${ }^{7}$

Yet, Russian society had difficulty in endorsing social mobility through education. For example, in August 1824, Kazan University reported that a state peasant, named Laptev, was qualified for admission but his mirskoe obshchestvo refused to vote to let him go. Laptev's fellow peasants had good reason to resist, of course, since releasing him would mean that his share of the commune's obligations would fall on them. The university requested that the ministry override the obshchestvo to permit his enrollment. Instead, the ministry persuaded the army to issue a receipt against the next recruitment, since providing recruits for the military was one of the peasant commune's most onerous obligations. Thus the peasant obshchestvo was persuaded to give Laptev his written release from his class, though the paperwork on all this was not completed until February $1826 .{ }^{8}$ Clearly, social mobility through education remained a complicated matter.

Nonetheless, the existence of the system caused anxious concern. Admiral A. S. Shishkov, appointed minister of education in 1824, thought it a mistake to offer general education to all classes, arguing that education, "like salt" should be applied "only as needed." Teaching a peasant to read and write did not offer the peasant a useful education. Indeed, rather than

7. In 1815 students released from the clergy were exempted from the requirements of presenting their documents to the Senate for confirmation upon completion of their course of study. Sbornik postanovlenii, 1:855-56 (Ob opredelenii. ... September 9, 1815). For the best discussions of this social aspect of Alexander's reform, see the following works of S. V. Rozhdestvenskii: "Vopros o narodnom obrazovanii i sotsial'naia problema v epokhu Aleksandra I," Russkoc proshloe, 5 (1923): 37-49; "Soslovnyi vopros v russkikh universitetakh v pervoi chetverti XIX veka," Zhurnal Ministersiva Narodnago Prosveshchcniia, May 1907, pp. 83-108 (hereafter cited as ZMNP).

8. Tsentral'nyi gosudarstvennyi istoricheskii arkhiv (Leningrad), fond 733, opis' 40, delo 121, listy 1-12 (hereafter cited as TsGIAL, f., op., d., list). This delo includes a spravka (listy 8-9), a document prepared by the staff for the guidance of the official responsible for a decision in any particular case, usually citing the legislation which seemed to apply and any precedents. Here, the spravka cited Alexander's ukaz of 1811 and a previous case, in which the army had issued a receipt against the military draft to a private landlord, persuading him to liberate a serf. The spravka drawn up in June 1826 on the case of a private serf, named Chekaevskii, cites the $u k a z$ of 1811 and the cases of state peasants admitted to Kharkov University. Ibid., d. 226, listy 4-6. Serfs and state peasants, then, were considered equally eligible for "scholarly service." 
producing well-trained, competent servitors of "God, Tsar, and Fatherland," as the original reformers had planned, the system failed to take into account "the situation of the people and the needs which each class has." Shishkov appointed a committee to study the whole educational system and to make recommendations for reform. The shock of the Decembrist revolt added to the sense of urgency and led to the appointment of many commissions to study reform. Two commissions were important for the educational system: the "Committee on the organization of academic institutions" and the "December 6, 1826" committee, which was charged with examining the whole state structure. $^{9}$

Both committees worked industriously for years, considering a great many projects and reports. Some complained that the nobility was in danger of being swamped with newcomers or that the state services were swollen with additional and superfluous personnel, while others argued that the nobility was too small a class to carry the main burden of state services, or that the services were badly undermanned and desperately needed a major influx of new, well-trained personnel. Some proposed that the nobility be made a closed caste by abolishing the Table of Ranks. Others proposed that the educational system be restructured clearly on class lines, offering separate schools to the various classes in conformity with the "true needs" of each class. Others, including the minister of education (1828-33), Count Karl Lieven, argued that Russia did not have a true class system, for service to tsar and nation, not only birth, determined a Russian's place in society. ${ }^{10}$ Hence, it would be impossible to build an educational system on the basis of hereditary class.

9. Shishkov's speech is printed in Sbornik rasporiashenii, 1:529. S. V. Rozhdestvenskii, in his Istoricheskii obsor deiatel'nosti Mintsterstva narodnago prosveshcheniia 18021902 (St. Petersburg, 1902), pp. 168-203, provides a detailed discussion of the work of the Committee on the organization of academic institutions, which hereafter, for brevity, will be called the "committee on schools." For well-focused discussions of the "December 6 Committee," see Torke, "Das russische Beamtentum," pp. 70-84; N. G. Sladkevich, "O soslovnykh proektakh komiteta 6 dekabria 1826 g.,"Issledovaniia po otechestvennomu istochnikovedeniiu (Moscow, 1964), pp. 274-83.

10. Rozhdestvenskii, Obzor, pp. 197-98. "In states," said Lieven, "where the division between classes is sharp and passing from one class to another, especially from middle to nobility, is very difficult and it is rare to reward long and distinguished service with a grant of nobility-in such states, I say, it is easy to organize education in that way [that is, on the basis of hereditary class]. But in Russia, where no middle or citizen class exists, where only the merchant class (kupecheskoc soslovic) in some way resembles one, where the artisan is in all respects the equal of the farmer . . . and where a well-off peasant may at any time become a merchant, and often is both at the same time, where the nobility extends from the foot of the throne at one end and nearly merges into the peasantry at the other, where every year many from the citizen and from the peasant class enter the ranks of the nobility by achieving the necessary rank in the military or civil service-in Russia it is very difficult to organize the schools in that way [that is, on the basis of hereditary class]." 
Nichoias intervened many times in the work of the committees, for he was very anxious to get something concrete accomplished. On one occasion, he wrote to Shishkov: "I order you to hurry up."11 Nothing much came of that order, except perhaps Shishkov's retirement, for the issues under debate were very difficult to resolve. Neither of the main committees could decicle whether the Russian educational system should serve the fatherland by providing a modern Western education for all who could qualify, or by upgrading the education available to each class so that each class could better serve its own "true needs."

Nicholas himself made a decision. On August 19, 1827, he issued an order to Shishkov. He wanted, he said, education which fostered the "true needs" of the state "neither below nor above" the condition of life in which "in the ordinary course of things [the student] will probably stay." At present, he went on, "it has come to my attention" that "often serfs [krepostnye lindi] from both towns and villages study in gymnasia and other higher educational institutions." The best of the serfs "in talent and success" aspire to a style of life "not suitable to their condition," leading "not seldom" to "dlangerous dreams or low passions." To curtail such "results" Nicholas said "I now find it necessary to order that admission to universities and gymnasia be restricted only to those of the free classes, not excluding also the emancipated ... though they may not have enrolled yet in the kupechestvo [merchants' orders] or meshchanstvo [townsmen] or have any kind of rank." 12

Nicholas's decision, despite the vigor and directness of his language, decided nothing. Restricting admission to free classes and those emancipated from obligated classes was no more than a restatement of the system developed under Alexander, a system whose usefulness for the "true needs" of the state was precisely what was being questioned in the committee on schools and elsewhere. Yet it was clear that while Nicholas wanted the educational system to take into account the "ordinary course of things," he

It may be useful to note that Lieven used the terms soslovic and sostoianie as interchangeable synonyms, while the ministry often used the term proiskhozhdenic as a synonym for either or both. See, for example, $Z M N P$, November 1836, p. 330. This apparent confusion helps to make clear that neither in law nor in practice did the Russian class system make the sort of clear distinctions between legal "estates," occupations, or even wealth, which were normal in the West. In regard to clergy, for example, "the term 'soslovic' was not used in the sense of corporate estate in the eighteenth century, but gained currency only in the mid-nineteenth century. . . . Both state and church documents . .." instead often used the terms "dukhovenstvo or sviashchennyi chin." G. L. Freeze, "Social Mobility and the Russian Parish Clergy in the Eighteenth Century," Slavic Review, 33, no. 4 (December 1974): 642, n. 3.

11. Ibid., p. 182.

12. Sbornik postanovlenii, vol. 2, sec. 1, pp. 71-73 (Reskript. . . August 19, 1827). 
remained unwilling to say flatly that a Russian should have to stay in the class to which he was born.

University reports during these years seldom made mention of the students' class origins. ${ }^{13}$ There were, of course, problems and decisions to be made, usually because a disagreement over class policy had arisen in a university. For example, in May 1829, the curator of Moscow University reported that "following the $u k a z$ of November 10, 1811," students "liberated from obligated classes" were granted the first degree. But their progress was delayed since the confirmation of the degree and release from their former class came from the Senate "usually in the middle of the year." The ministry promptly ruled that the degree should be dated from the time the student passed the exam, not the Senate confirmation. In the view of the ministry, then, Senate confirmation was a formality; the student had left his class by virtue of success in academic work. ${ }^{14}$

In December 1832, the curator of Kazan University wrote to the ministry that a state peasant, named Kurteev, had applied for admission. His papers were in order, including his "emancipation" from his obshchestvo. The faculty council wanted to admit him. But the curator, referring to Nicholas's reskript of August 1827, thought it best to admit Kurteev only on condition that he enter the teacher-training program. The curator apparently thought that since serfs ordinarily entered either medicine or teacher training, he was justified in imposing that condition of admission. The ministry disagreed, ruling that, as with any student, if Kurteev entered as a state student he could be held to a proscribed program; but if he entered as a self-supporting student, he was free to choose his course. Obviously, there remained ambiguities in the interpretation of the meaning of "ordinary." 15

13. For examples, TsGIAL, f. 733, op. 49, d. 43, list 4 (Kharkov University report for 1826-27); ibid., op. 29, d. 163, list 5 (Moscow University report for 1829-30). For typical cases, see the reports for St. Petersburg University 1827-28 and 1830-31, printed in S. V. Rozhdestvenskii, ed., S. Peterburgskii Universitct v pervoe stolctie ego deiatel' nosti: Materialy po istorii S. Peterburgskogo Universiteta: 1819-1835 (Petrograd, 1919), pp. 636-40, 706-9. The most successful effort to draw up a complete picture of the class composition of the student bodies is Iu. N. Egorov, "Reaktsionnaia politika tsarizma v voprosakh universitetskogo obrazovaniia v 30-50kh gg. XIX v.," Nauchnye doklady vysshei shkoly: Istoricheskie nauki, 1960, no. 3, pp. 60-75.

14. TsGIAL, f. 733, op. 29, d. 169, listy 1-2 (May 7, 1829); list 4 (May 16, 1829).

15. Ibid., op. 41 , d. 58 , listy $1-2,5-6$. Since neither teaching nor medicine was likely to lead to promotion to the higher echelons of the bureaucracy, they remained low prestige occupations in a society dominated by the concepts of the Table of Ranks. The law faculty, which prepared students for careers more likely to result in promotion to the upper reaches of the state administration, remained the most popular faculty, particularly for students from noble families. However, it was not unusual to find sons of those emancipated from "obligated classes," who had earned low or middle rank in service as teachers or doctors, enrolled in law faculties. Although delayed a generation, this was also social mobility through education. 
Uvarov, who had served as curator of St. Petersburg University (181021 ), as well as with the committee on schools, became minister of education in March 1833. Nicholas, four years later, anxiously reminded Uvarov that education in Russia should meet the "true needs" of each class and that access to higher education was subject to "well-known" and "definite" conclitions. For nobility, the condition was success in "severe examinations"; for townsmen and "free peasants" (Nicholas's term for state peasants), liberation from obligations by their obshchestvo; for serfs, liberation by their masters. He granted that "violations of these rules in public schools have been few," but said that in private schools violations "are still often found" and charged Uvarov to see that the rules were strictly observed. ${ }^{16}$ This order, of course, changed nothing, for it simply restated the existing regulations. Yet, it did indicate that Nicholas was distressed because social mobility was taking place through education, although he was unwilling to stop it, continuing to hope that strict enforcement of the existing rules would somehow prove adequate.

Two years later, in 1839, Uvarov took steps to introduce tuition. In March of that year the curator of St. Petersburg University requested permission to charge tuition of self-supporting students. The additional income was badly needed since the university budget did not supply funds adequate for even routine maintenance. Uvarov enlarged upon the curator's plea in his own proposal to the Committee of Ministers, pointing out that the university had been using funds allotted for faculty salaries to compensate for the inadequacies of the maintenance budget. Since that practice could not continue, the university needed an additional source of income. His proposal included the introduction of tuition in all the universities, not just St. Petersburg, both for maintenance and as a "source of aid for the poorest of the university students." 17

In October 1839, Uvarov, announcing the tsar's approval of the new tuition program, promulgated a regulation that self-supporting students would pay 100 rubles (paper, or 28.57 in silver) at St. Petersburg and 50 rubles (or 14.29 in silver) at Kharkov and Kazan-a similar rule was promised for Moscow and St. Vladimir (Kiev) in the near future. Excused from paying were all state students as well as self-supporting students who could not afford it, and faculty children. The money collected was to be used, first, to

16. Sbornik postanovlenii, vol. 2, sec. 1, pp. 1258-60 (Reskript . . . May 9, 1837). Uvarov, quoting this reskript, reminded the curators that "universities may not admit people from obligated classes before presentation of notice of their liberation from [their] obshchestvo." $Z M N P$, April 1838, pp. ix-xii. It is worth noting that these "well-known" regulations did not find their way into the statutes for gymnasia and lower schools, Sbornik postanovlcnii, vol. 2, sec. 1, pp. 200-257 (December 8, 1828), and the statute for universities, ibid., pp. 969-95 (July 26, 1835).

17. Sbornik postanovlenii, vol. 2, sec. 1, pp. 1480-85 (March 21, 1839). 
aid "poor self-supporting students." Second, it could be used to support "poor state students." Third, funds could be applied to compensate for shortages in the maintenance budget. No mention was made of the class origins of any students, either as payers of tuition or recipients of aid. ${ }^{18}$

Uvarov, however, soon had occasion to mention the class issue. Nicholas made a visit to St. Vladimir University in 1840 and was dissatisfied, complaining to Uvarov of the shabby appearance of many of the students, which he attributed to their social background. Uvarov responded with a proposal to Kiev, soon expanded in a circular to the other universities, suggesting that Kiev use some of the funds collected in tuition to support instruction in dancing, fencing, and gymnastics. This, apparently, was Uvarov's view of what Nicholas would notice when inspecting an institution of higher learning. In any event, Uvarov suggested that the university curators discourage the admission of students "who have received no external polish in the homes of poor parents of low origins. . . "However, measures to keep out such students "must be taken in every case with the ttmost discretion." Attention should be paid to the social background of students in order to ensure that the education received would be consistent with the probable future life of the student, and curators "with plausible excuses should prevent admission to universities of those unable to compensate for their lack of external polish by excellent academic ability." Pointing out that "in this regard it is difficult to set definite limits" on admitting students of low origins, Uvarov asked for suggestions from the curators. ${ }^{19}$

18. $Z M N P$, October-December 1839 , sec. 1, pp. 22-28, reprinted in Suornik rasporiazhenii, 2:426-31 (Pravila sbora deneg .... October 10, 1839). The exemption granted faculty children seems an unnecessary gesture. Faculty salaries ranged from 5,000 rubles a year for full professors at Moscow and St. Petersburg, with a housing allowance of 500 rubles, down to 2,000 rubles (with a housing allowance of 300 rubles) for adjuncts-that is, instructors-at the "provincial" universities. At the same time, junior clerks received 250 rubles a year, senior clerks 600 rubles. State students had stipends of 500 rubles a year, which was probably more than the cash income of at least half, possibly three-quarters, of the serf-owning gentry. In any event, tuition of 100 rubles would have been a severe financial strain for most gentry and officer families, but not for university professors. Blum, Lord and Pcasant, pp. 451-70; Emmons, Landed Gontry, pp. 3-4, 24-29. For the university salary scales, see "Shtaty i Prilozheniia," Sbornik postanovlenii, vol. 2, sec. 1, pp. 34-36. Comparing incomes in Nicholas's time is difficult, however, not only because of the importance of nonmonetary forms of income in a serf-agricultural economy but also because several different ways, and exchange rates, were used to calculate the relationship between silver and assignat rubles. On this problem see Pintner, Economic Policy, pp. 256-63. Nonetheless, it is quite clear that the salaries of middle rank, let alone junior, officials in both military and civil service were strikingly low. See S. F. Starr, Decontralization and Self-Government in Russia 1830-70 (Princeton, 1972), pp. 21-22; J. S. Curtiss, The Russian Army under Nicholas I, 1825-1855 (Durham, N.C., 1965), p. 254.

19. Sbornik rasporiazhcnii, 2:485-87 (Predlozhenie Popechiteliu Kievskogo. . . . October 22, 1840); ibid., pp. 494-96 (Tsirkuliarnoe predlozhenie. . . December 31, 1840) 
While the curators agreed that no definite legal barriers to admission of students of low origins should be imposed, some suggested that one could impose tuition on them, or forbid their acceptance as "state students," or deny them the right to enter state service on the basis of education. Any of these steps, of course, would have changed the situation, for they would make it more difficult, or remove the motive, for lower class students to pursue higher education. Count S. G. Stroganov, curator of Moscow University, however, argued that any steps to curb admission of lower class students would have "dangerous consequences for public education."20

Uvarov took no action on any of the curators' suggestions, except Stroganov's. Uvarov delayed the introduction of tuition at Moscow at Stroganov's request. Stroganov wanted a whole series of understandings which permitted the University to distribute the funds collected to support needy students of all classes, specifically for those who fell ill or needed help with other special problems. He wanted to make clear that those who had not the means, and also children of former and present faculty, were exempt from tuition, and he particularly wanted to work out an effective reporting system so that the University could have accurate information on the students' financial situation before deciding who should pay. Uvarov readily agreed with all of Stroganov's requests and drew upon some of them in framing "supplementary rules for freeing students from tuition payments" issued in 1841.21

Uvarov knew, of course, that the introduction of tuition made no discernible difference in the class origins of university students. Indeed, judging from the figures he published, he did not think students' class origins important enough for the universities to keep very careful records of them. ${ }^{22}$

Uvarov wanted the curators to think up "plausible excuses" because he ordered that only the curator and rector of the university-not the faculty, and certainly not the students or the general public-should know of this directive.

20. The responses of the curators are summarized and quoted in Rozhdestvenskii, Obะor, pp. 254-55.

21. Uvarov-Stroganov correspondence April 24, 1841-November 19, 1842 in TsGIAL, f. 733 , op. 30 , d. 185 , listy $277-93,310-11$; Sbornik rasporiashenii, 2:535-36 (Dopolnitel'nyia pravila .... December 19,1841 ).

22. In 1841 Uvarov published a set of "statistical tables" on the universities which included a breakdown of students by class origins. $Z M N P$, October 1841 , sec. 3, pp. 3235. The tables show little effort at precision, for each university used different terms. Moscow, for example, reported merchants, townsmen, orphans, and "liberated." Kazan used none of these terms but instead listed students from "obligated classes" and "of unknown origins." Uvarov made no apparent effort to encourage more precise reporting, even by demanding clarification of the terms to be used. Given the somewhat muddled character of the class system, as well as the inconsistency in the universities' reporting, it is not possible to draw up a completely clear picture of the class origins of students. Nonetheless, studies which place clergy under "raznochintsy" (as does Egorov 
In 1843, he made a "ten-year" report to Nicholas on the accomplishments of his first decade in office, pointing out how splendidly all aspects of education were faring. His report included the information that "even serfs" were not excluded from the joys of education, although for their own good they were subject to "definite rules" which were "always strictly" observed. ${ }^{23}$ The rules described here were those which had come into force by 1815 , however, not any new tightening up designed to keep out more students of low origins.

Yet, anxious concern for the stability of the state and the social system continued to agitate many, including Nicholas. In December 1844, Uvarov provided the tsar, apparently at Nicholas's request, with a list of steps which might be taken to "moderate the influx of students into institutions of higher learning." However, Uvarov pointed out that any such steps would have to be made "quietly and unofficially" to preserve the social order "without clearly destroying the basic principles upon which the state has operated for a whole century. ... If Uvarov meant to defend the existing system in the universities, this was a useful argument, for although Nicholas clearly wanted social mobility contained, he would not willingly violate a "basic principle" upon which Russia had run for a century. ${ }^{24}$

In June 1845, Uvarov decided that the universities required additional funds to aid needy students, but he realized that increases in state appropriations were unlikely. He requested the tsar's permission to increase tuition for self-supporting students, up to 40 rubles (silver) at Moscow and St. Petersburg, 20 rubles at the others. ${ }^{25} \mathrm{He}$ made a four-point argument that the

in "Reaktsionnaia politika," Nauchnye doklady) or with "officers" (as does T. B. Riabikova in "Chislennyi $\mathrm{i}$ soslovnyi sostav studentov Moskovskogo universiteta," Vestnik Moskovskogo Universiteta, 1974, no. 5, pp. 57-67) are less precise than necessary, for university reports which listed students' origins never failed to list clergy as a separate class.

23. S. S. Uvarov, Desiatiletie Ministerstza narodnago prosveshcheniia 1833-1843 (St. Petersburg, 1864), p. 11.

24. Rozhdestvenskii (Obzor, p. 255) provides a summary of, and quotations from, Uvarov's report to the tsar, December 1,1844 . The growth in total university enrollment, from approximately 1,500 in 1836 to 2,500 in 1844 to 3,400 in 1848 , troubled Nicholas. Rising total numbers obviously meant a larger number of students from "low classes" each year, yet the social composition of the student bodies changed hardly at all-the "free" classes provided the clear majority of students. For example, Egorov ("Reaktsionnaia politika," Nauchnye doklady, tables 1 and 3) reports that gentry and officers made up 66.9 percent of the students in 1836 and 67 percent in 1848. There were wide differences between universities, but these also were constant over time. For example, after 1835 at Moscow University, gentry were never less than 45 percent of the students but never as much as 50 percent, while at Kiev the gentry were never less than 75 percent. At the other extreme, at Kazan gentry were never less than 25 percent of the students but never as much as 30 percent.

25. Sbornik postanovlenii, vol. 2 , sec. 2 , pp. $629-32$ (O vozvyshenii platy . . . June 11, 1849). 
increase was necessary. The first three points indicated that the universities needed more funds and could not get them from the regular budget. His fourth point added that "in institutions of higher and secondary education it is clear that there is a rising influx of young people, partly of those born in the lower social orders, for whom higher education is not useful, but only a luxury which takes them away from their original [life] situation, without benefit to them or to the state." 26 Therefore, Uvarov requested a tuition increase "both for the strengthening of the schools' budget and to contain the striving of youth for education." Uvarov did not say it, but his proposal seemed to suggest that an increase would tend to discourage students from low classes.

Nicholas immediately accepted Uvarov's proposal, but added two noteworthy points. First, he scaled upward the tuition charges to 50 rubles at Moscow and St. Petersburg, 40 rubles at the other universities. Second, he asked, almost plaintively, "are there no means of making it difficult for raznochintsy to enter gymnasia?"27 Uvarov, startled or stung, replied at once. He said that he "had already taken decisive measures on this subject" by proposing to the Committee of Ministers that children of merchants and other obligated classes not be admitted to gymnasia without written authorization- "liberation certificates"-from their class authority. Gymnasia, he pointed out, were "preferably" for the education of nobles' and officers' children. But, he added, this "measure regarding children of the middle class is separate from the raising of tuition."

It is doubtful that Nicholas found Uvarov's proposal a decisive measure, for it only repeated the regulations in effect before 1815 (even though Nicholas had done no more himself in his reskripty of 1827 and 1837). Moreover, he seemed to want the class question and tuition joined. But if Uvarov, in his proposal, had suggested a link, now he had changed either his mind or his line, for he concluded his reply to Nicholas by "respectfully begging" that

26. By omitting the words "partly of those" from Uvarov's text, Miliukov (Ocherki, 4th ed., vol. 2 [St. Petersburg, 1905], p. 353) changes his meaning. Florinsky (Russia, 2:802) reproduces Miliukov's error.

27. See Nicholas's notations on Uvarov's request in Sbornik postanovlenii, vol. 2 , sec. 2, pp. 629 and 631. Nicholas apparently used the term raznochintsy to mean "low born" in general. Though often used in official records, the term had no precise legal meaning. In 1831 the curator of Kazan University requested a ruling from the Ministry of Education on just who should be considered "rasnochintsy." The ministry had to admit that, since the only law which used the term was an unhelpful regulation on bankruptcies issued in 1800 , the term had no clear meaning. Yet the ministry gave a long list of those who might be considered rasnochintsy, including retired military personnel and various government functionaries serving in posts below those listed in the Table of Ranks. Unfortunately, to this list the ministry added "and others." Sbornik rasporiazhenii, 1:801-2 (Po voprosu. . . July 22, 1831). The best discussion of the term remains Christopher Becker, "Raznochintsy: The Development of the Word and of the Concept," American Slavic and East European Revievu, 18, no. 1 (1959): 63-74. 
Nicholas's projected tuition increases be postponed for five years. He argued that it would be "dangerous suddenly to increase tuition," for that might make it difficult for the state system to compete with private schools. "This danger," he admitted, "is not so great in the empire as in the Kingdom of Poland." But, he added, "I will not hide from Your Majesty that in the southwestern parts of the empire [the Kiev district] it is an especially important consideration." Uvarov did not explain why he had not thought of all this only five days earlier when he made his proposal to increase tuition. But by connecting the tuition issue with the possibility of danger in the western provinces; Uvarov won his point, for Nicholas agreed to postpone his tuition increase, though only for three, not five years. ${ }^{28}$

The new tuition schedule published by the ministry contained no reference to any of these issues, but said only that the funds collected were to be used first of all for the support of needy students, making no mention of class or social origins. ${ }^{29}$ In his reports to the ministry, however, the curator of Moscow University wanted very much to discuss the origins of students; and the tuition issue. In October 1847, Stroganov stated that every year requests for aid mounted, while the funds collected remained limited. He wanted permission in the future to grant aid only to the best students, ordinarily only to second year men who had demonstrated academic excellence in their first year of study. Stroganov described in some detail the proposed regulations that would use available grants only for rewarding first-rate academic performance. He did not mention class origins in any way. But he did point out that "natives of the western and other separated provinces" were a problem, for they came in "constantly growing numbers" and "the majority are poor, having no means of self-support at all." The result was that "they strive in this university" to secure support "from the sums collected from students who are natives of the Great Russian provinces." Thus, Stroganov appeared unconcerned about the class issue, but offended that the funds of Russians were going to support Poles and other "separated" peoples. He requested permission to place limits on the funds available to "natives of the western provinces" and to clear the air by publishing the new rules in the newspapers. ${ }^{30}$

28. Sbornik postanovlenii, vol. 2 , sec. 2, pp. 632-34 (O merakh k zatrudneniiu. . . . June 14, 1845).

29. ZMNP, May-June 1845, sec. 1, pp. 31-39, reprinted in Sbornik rasporiaz/lenii, 2:818-24 (Polozhenie o vzumanii. . . June 15, 1845).

30. Stroganov to Uvarov, October 8,1847 , in TsGIAL, f. 733 , op. 33, d. 172 , listy 1-3. Stroganov (list 2) said that the tuition income amounted to less than 2,500 rubles. This would indicate that only about 85 students paid the full tuition, that is, that tuitionpaying students were probably fewer than 10 percent of the student body, which was over 1,300 in 1848. At least 30 percent of Moscow University students received some sort of aid. Approximately half the aid recipients were gentry. Most aid at Moscow was restricted. "State" stipends were available only to students in medicine or teacher train- 
Uvarov readily agreed to Stroganov's suggestions. He knew, of course, that Stroganov had long opposed any steps to limit education on class lines and had no difficulty in granting Stroganov permission to distribute aid "under your own management." But, he added, "I find it unnecessary and not useful to publish these regulations for public information." 31 Uvarov was satisfied with the system, but clearly wanted to attract as little discussion as possible.

Neither Uvarov nor. Stroganov were to remain in office much longer, for in 1848 the situation changed completely. However, Uvarov had long made clear his policy and his motives. He believed in the existing system, which included the preeminence of the nobility, the institution of serfdom, and the rank system provided by the founder of imperial Russia, Peter the Great. In 1847, when proposals were again made to abolish the rank systemto make the Russian class system one of closed castes, or of none-Uvarov dropped his usual guarded, moderate stance. In an impassioned defense of "the higher meaning" of the rank system, Uvarov argued that while in other countries inclusion in the upper classes depended on "birth, wealth, or even gifts," in Russia the key element was "service." The basic strength of the whole system was, indeed, its "equality before the law." Thus, "the son of a famous lord or the richest landholder, entering the field of state service, has in law no advantage except the advantage of constant zeal and in this he may well be matched by the son of a poor father of unknown merits." Rather than leave "Russia's future" to a system based on birth or wealth, Uvarov urged Nicholas to stand by the existing system. ${ }^{32}$

Uvarov, for years, had reported that the educational system was making splendid progress, needing only more time to achieve its goals. He hoped to continue the existing policies and, therefore, rather than challenging the tsar with the direct argument that Nicholas's fears wildly exaggerated the

ing, while other aid funds were restricted to graduates of certain gymnasia, natives of certain cities or provinces, and so on. One fund was limited to students whose parents had perished in the 1831 cholera epidemic. Stroganov would break new ground, then, in restricting aid on the basis of academic achievement. See Riabikova, "Sostav studentov," Vestnik M.U., p. 66; L. I. Nasonkina, Moskovskii universitet posle vosstaniia dekabristov (Moscow, 1972), pp. 32-38.

31. Uvarov to Stroganov, November 8, 1847, in TsGIAL, f. 733 , op. 33, d. 172 , list 5.

32. Uvarov's report to Nicholas, February 1847, is printed in Evreinov, Grazhdanskoc chinoproisvodstio, pp. 82-85. Uvarov, of course, was neither the first nor the last to believe the promise of Russian institutions superior to the alternative presented by the West's "bourgeois" value system. Herzen, for example, sought his "home" not in the "West," but "among the alienated radical intellectuals of the West." This point is particularly well made in D. W. Treadgold, The West in Russia and China, vol. 1 (Cambridge, 1973), p. 178. 
degree of danger, Uvarov reported that despite the dangers, the educational system was well ahead of the problems. Faced with Nicholas's increasing excitement and fear at the events of 1848 , Uvarov submitted a special report, pointing out that the able, devoted work of university faculty and students alike showed that there was no possibility of danger to the state arising within the university. Nicholas replied: "I don't believe it."33 Uvarov had lost the tsar's confidence and his dismissal was not long delayed. Yet, Uvarov had succeeded in minimizing the impact of Nicholas's emotions and fears for a remarkably long time by assuring the tsar of loyalty and progress, while playing down, to the point of forbidding outright, discussion of sensitive matters which might attract the tsar's agitated interest, such as the issue of tuition and its relationship to admission policy. While Uvarov was minister of education the system inherited from Alexander I remained substantially intact, despite the clear wishes of Nicholas that something be done to reduce its social impact. Moreover, the system remained substantially intact even after Uvarov's dismissal.

Uvarov's successor, P. A. Shirinskii-Shikhmatov, took up the class question again in January 1850 . His report to Nicholas pointed out that the university system had been founded in the early years of the century so that "as quickly as possible" the government could "staff all parts of the state administration with men especially prepared for service." But the number of men prepared for university work was "so small" that it had been necessary "to admit ... all young people, without distinction, who had the ability to pass the entrance examination. Thus began the admission of [students from the] obligated classes to higher education in the universities and the opening to them, through education, of admission to military and civil service on terms of equality with the nobility." Now he complained, "as before, the doors of the universities remain open to all classes." He asked, "would it not be possible ... to reserve these vacancies primarily for the young men who, by their birth and by the basic law of the state, have been given the right to enter state service?" Yet, university enrollments to the end of Nicholas's reign showed no discernible change in the class composition of the student bodies. Of course, Shirinskii-Shikhmatov had said that university vacancies should be preserved "primarily" for nobles, not exclusively. Thus, despite Uvarov's departure, neither his successor nor Nicholas could bring themselves to change the system fundamentally. ${ }^{34}$

33. TsGIAL, f. 735, op. 10, d. 293b, list 646 (October 24, 1848); and Nicholas's response to Uvarov's report in ibid., listy 647-61 (October 22, 1848). For an example of Uvarov's reporting, see "Obshchii otchet . . za 1846 god," ZMNP, April 1847, p. 12"it may be seen that the time is not far off when the brilliant harvest will be completed finally...."

34. Shirinskii-Shikhmatov's report is printed in Sbornik postanovlenii, vol. 2, sec. 
Reduced to essentials, Nicholas's Russia faced a dilemma: should Russia maintain her own values, which included, of course, her social and rank system, or should she meet her obvious needs for economic and technical progress by abandoning her Petrine inheritance? In terms of university class policy, this meant choosing between closing the universities to all but nobles and officers' sons (perhaps allowing others only in the medical or teachertraining programs), or abandoning class considerations in university admissions. Either choice not only would violate a valued part of the Russian tradition but also call up a host of practical difficulties. ${ }^{35}$

Uvarov carefully drafted the legislation on tuition so that it was not a barrier to lower class students but rather provided funds to support poor students regardless of class origins. He failed to prevent the influx of lower class students to higher education, therefore, not because he could not prevent it, but because he did not want to do so. Of course, Uvarov had no difficulty in agreeing that the schools "ordinarily" should run on traditional class lines. Nicholas also agreed with Uvarov that no definite legal class barriers to higher education should be raised-while that might defend the existing class structure, it also would violate the treasured principle that a Russian owed his place in society, in the highest sense, to his service to "God, Tsar, and Fatherland."

It may be argued, in retrospect, that Uvarov was wrong, for the problem was not whether he could prevent the tsar, or for that matter some radical faculty members, from shaking up the system. The problem was, rather, could the system in which Uvarov believed meet Russia's needs? The Crimean War would soon convince many that it could not. Yet, Uvarov's inability, or unwillingness, to foresee the necessity for genuine radical change does not mean that he was the caricature reactionary figure who increased tuition fees in order to keep out "democratic" elements-a figure fit only for consignment to the dust bin of history. He was, rather, an able, hard-working patriot, whose life work has been disparaged because the requirements of modernization have,

2, pp. 1137-38 (O priniatii v universitety ... January 26, 1850). For enrollment figures in the post-Uvarov years, see Egorov, "Reaktsionnaia politika," Nanchnye doklady, pp. 66-67, tables 4 and 5. The figures show a slight decrease in the percentage of noble and "officer" sons at St. Petersburg and Kazan, a slight increase at the others.

Since very few students paid the tuition (see note 30 ), it is not surprising, of course, that the impact of the tuition charges was slight.

35. The point is not that we now know large scale modernization invariably has destroyed traditional class structures (for an excellent discussion of this experience, see D. E. Apter, The Politics of Modernization [Chicago, 1967], pp. 43-141), but that contemporary Russians so perceived the choices. For a detailed description and analysis of Russia's needs, as well as the contemporary views, see Starr, Decentralization and SelfGoverment in Russia 1830-1870, pp. 3-109. 
historically, not been kind to the sort of moderate, prudent, balanced, that is, half-way, measures to which Uvarov was committed. ${ }^{36}$ A radical choice, either full scale adoption of "open admissions" or restriction of admissions to "nobles and officers," would have required Uvarov to scrap his most cherished loyalties. Not only "reactionaries," but honest patriots, too, have found such a price for progress simply too high to envision, let alone bear.

36. For statements of Uvarov's belief in Russia's promise and the need for time to allow beneficial progress, see his Rech' prezidenta imperatorskoi Akademii Nauk, popechiteliia SPB uchebnogo okruga ... 22 marta 1818 goda (St. Petersburg, 1818) and his article "Podvigaetsia li vpered istoricheskaia dostovernost'?," Sovrcmcmik, 1851, no. 1, pp. 121-28. While less sanguine in 1851, it does not appear that Uvarov changed his mind on fundamentals. For excellent analyses of the 1818 speech, see C. H. Whittaker, "Count S. S. Uvarov: Conservatism and National Enlightenment in PreReform Russia" (Ph.D. diss., Indiana University, 1971), pp. 93-103; V. V. Pugachev, "K voprosu o politicheskikh vzgliadakh S. S. Uvarova v 1810-e gody," Uchenye zapiski Gor'kovskogo universiteta, no. 72 (1964), pp. 127-31. 